\title{
Molluscicidal Effect of Nicotinanilide and its Intermediate Compounds against a Freshwater Snail Lymnaea luteola, the Vector of Animal Schistosomiasis
}

\author{
D Sukumaran+', BD Parashar, AK Gupta, K Jeevaratnam, Shri Prakash
}

Defence Research \& Development Establishment, Jhansi road, Gwalior - 474 002, India

The molluscicidal effect of nicotinanilide was evaluated and compared with niclosamide (2',5-dichloro-4'nitrosalicylanilide, ethanolamide salt) against different stages of the freshwater snail Lymnaea luteola i.e., eggs, immature, young mature, and adults. Calculated values of lethal concentrations $\left(L C_{50}\right.$ and $\left.L C_{90}\right)$ showed that both nicotinanilide and niclosamide as toxic against eggs, immature, and adults. The young mature stage of the snails was comparatively more tolerant to both molluscicides than the other stages. The toxicity of the intermediate compounds of nicotinanilide against the young mature stage of the snails showed them as ineffective. The mortality pattern of the snails exposed to $L_{90}$ concentration of these molluscicides showed niclosamide to kill faster (within 8 to $9 \mathrm{~h}$ ) than nicotinanilide (26 to $28 \mathrm{~h}$ ).

In view of the above studies it may be concluded that both molluscicides are toxic against all the stages of the L. luteola snails.

Key words: nicotinanilide - niclosamide - molluscicide - Lymnaea luteola - animal schistosomiasis - snails as vectors

Schistosomiasis, a dreadful disease caused by parasitic trematode worm in both humans as well as in animals is widespread in the world especially in developing countries (Engels et al. 2002). It is considered second only to malaria as a major target disease of the World Health Organization (Xiao et al. 2002). Various species of freshwater snail act as intermediate hosts of schistosomiasis (Malek \& Cheng 1974). The snails belonging to the family Lymnaeidae are known to act as intermediate host of both human and animal fascioliasis (Horak \& Kolarova 2001). The freshwater snail Lymnaea luteola Lamarck (Mollusca: Gastropoda), is widely distributed in India and acts as intermediate host of Schistosoma incognitum, S. nasale, Orientobilharzia dattae, Fasciola hepatica, F. gigantica, the causative agents of fascioliasis among cattle and cercarial dermatitis in human beings in the Northern part of India (Malek \& Cheng 1974, Singh \& Agarwal 1981, Jairajpuri 1991, Agrawal et al. 2000).

Control of snails is regarded as one of the best preventive measures in controlling schistosomiasis (Madsen \& Christiansen 1992, WHO 1993, Lardans \& Dissous 1998) where use of mollusciciding has given very satisfactory results (WHO 1993, Sturrock 1995). Studies on chemical structure - biological activity relationship of various compounds have permitted the identification of two compounds namely niclosamide (2',5-dichloro-4'-nitrosalicylanilide, ethanolamide salt) and nicotinanilide with most of the properties required for "the molluscicide molecule"

${ }^{+}$Corresponding author. Fax: +0751-2341148. E-mail: devanathansukumaran@yahoo.co.in

Received 15 August 2003

Accepted 12 January 2004
(WHO 1993, DeSouza 1995). Niclosamide is currently recommended by WHO in snail control programmes (Sturrock 2001, WHO1993) in spite of its toxicity to fishes even at below molluscicidal concentration (Marking \& Horgan 1967). In US, bayluscide (niclosamide) is registered as a piscicide and used more to control sea lamprey and trash fishes than snails (Schreier et al. 2000). Nicotinanilide is reported with high snail toxicity and no fish toxicity at molluscicidal concentration (DeSouza \& Paulini1969). It is also reported to be very safe to fishes, non-target organisms and mammals in addition to its cercaricidal property against cercariae of schistosomes (Tang et al. 1986, Parashar et al. 1990). Even though reports are available on the toxicity of nicotinanilide against some snail vectors (Dunlop et al. 1980, Wang \& Sung 1990, Cheng et al. 1991, Parashar et al. 1990, 1995), a detailed study on its molluscicidal effects is lacking. Hence, studies on the molluscicidal property of nicotinanilide as well as its intermediates like nicotinic acid hydrochloride, aniline hydrochloride and nicotinyl chloride hydrochloride were carried out against L. luteola snails keeping niclosamide as standard.

\section{MATERIALS AND METHODS}

Chemicals - The molluscicide nicotinanilide as a hydrochloride salt form (>99\% pure) as well as the possible intermediates of nicotinanilide such as aniline hydrochloride, nicotinic acid hydrochloride, and nicotinyl chloride hydrochloride were synthesised by the Synthetic Chemistry Division of Defence R\&D Establishment, Gwalior. M/S Bayer AG, Germany supplied the niclosamide (bayluscide $70 \% \mathrm{WP}$ ) as a free sample.

Snails - The freshwater snails L. luteola were taken from laboratory culture maintained in enamel bowls filled with dechlorinated water at room temperature $28 \pm 2{ }^{\circ} \mathrm{C}$ and relative humidity more than $75 \%$. They were fed with spinach ad libitum and the water was changed twice in a 
week. The egg strips containing $\quad 0-24 \mathrm{~h}$ and $72-96 \mathrm{~h}$ old eggs were used to study the ovicidal effect of molluscicides and the snails of different sizes i.e., immature (3-6 $\mathrm{mm}$ ), young mature $(9-12 \mathrm{~mm}$ ), and adults (more than 12$\mathrm{mm}$ ) were used for the toxicity studies.

Toxicity studies - The toxicity of nicotinanilide and niclosamide was screened as described by WHO (1965). In the case of ovicidal action, the total number of eggs in each egg strip was counted using dissection microscope before exposure to $200 \mathrm{ml}$ of test solutions kept in the petri dishes. They were exposed for $24 \mathrm{~h}$ and then transferred to normal water for further $24 \mathrm{~h}$. Disintegration of embryos or absence of movement of the embryos was considered for calculating the per cent mortality of eggs. The toxicity of molluscicides against adult snails was carried out with ten L. luteola snails of each stage. They were exposed to 21 of water in enamel bowls containing the different concentrations of the molluscicides for $24 \mathrm{~h}$. After exposure, they were transferred to normal water for further $24 \mathrm{~h}$ and later the percent mortality of snails was calculated. All the experiments were replicated six times. The data obtained from the above studies were subjected to probit analysis (Finney 1971) to calculate $\mathrm{LC}_{50}$ and $\mathrm{LC}_{90}$ values. Similarly the $\mathrm{LC}_{50}$ and $\mathrm{LC}_{90}$ values of the intermediates of nicotinanilide were calculated against the least susceptible young mature stage of L. luteola snails.

Mortality pattern of the snails - The least susceptible young mature stage of $L$. luteola snails was used for this study. Ten snails in each of two groups were exposed to 21 of tapwater containing $\mathrm{LC}_{90}$ concentration of nicotinanilide and niclosamide respectively. Soon after exposure, they were continuously observed at an interval of every $30 \mathrm{~min}$ for mortality. Extrusion of the whole headfoot region permanently outside the shell or lack of any movement of the body when touched with tip of the needle was considered to determine mortality of the snail. The duration required for the mortality of all the snails was recorded. The dead snails were removed immediately from the enamel bowl. The experiment was replicated six times. The mean duration required for the death of the snail was calculated and the data were statistically analyzed and subjected to regression curve using sigma plot.

\section{RESULTS}

The $\mathrm{LC}_{50}$ and $\mathrm{LC}_{90}$ values of nicotinanilide against eggs, immature, young mature, and adult stages of $L$. luteola are shown in Table I and mentioned in Figs 1 and 2 . The $\mathrm{LC}_{90}$ values against the eggs of $0-24 \mathrm{~h}$ old and $72-$ $96 \mathrm{~h}$ old are calculated as 0.76 and $0.70 \mathrm{ppm}$ respectively. In the case of different growing stage of snails namely immature, young mature, and adults, the $\mathrm{LC}_{90}$ values are calculated as $0.67,2.32$, and $1.39 \mathrm{ppm}$ respectively. The calculated values of $\mathrm{LC}_{50}$ and $\mathrm{LC}_{90}$ of niclosamide against the same snails are given in Table II and expressed in Figs 1 and 2. The values of $\mathrm{LC}_{90}$ of niclosamide against eggs of 0-24 h old and 72-96 h old are calculated as 0.71 and $0.38 \mathrm{ppm}$. Similarly the values of $\mathrm{LC}_{90}$ of niclosamide against growing stages of adults are calculated as 1.04 $\mathrm{ppm}$ for immature stage, $1.41 \mathrm{ppm}$ for young mature stage, and $0.45 \mathrm{ppm}$ against the adults.

The calculated values of $\mathrm{LC}_{50}$ and $\mathrm{LC}_{90}$ of the intermediate chemicals of nicotinanilide against the least susceptible young mature stage of L. luteola are given in Table III and mentioned in Fig. 3. The results show the $\mathrm{LC}_{90}$ value for nicotinic acid hydrochloride as $371.32 \mathrm{ppm}$, for aniline hydrochloride as $310.87 \mathrm{ppm}$ and for nicotinyl chloride hydrochloride as $210.39 \mathrm{ppm}$ respectively.

The overall results from the mortality pattern of the young mature stage of L. luteola snails exposed to $\mathrm{LC}_{90}$ concentrations of nicotinanilide and niclosamide are shown in Fig. 4. Complete mortality of all snails occurred within 6 to $8 \mathrm{~h}$ when exposed to niclosamide whereas for nicotinanilide it required between 26 and $28 \mathrm{~h}$ after exposure.

\section{DISCUSSION}

Ovicidal action of nicotinanilide against $L$. luteola shows the compound to be more toxic to the $72-96 \mathrm{~h}$ old eggs $\left(\mathrm{LC}_{90}\right.$ value is $\left.0.70 \mathrm{ppm}\right)$ than the $0-24 \mathrm{~h}$ old eggs $\left(\mathrm{LC}_{90}\right.$ value is $\left.0.76 \mathrm{ppm}\right)$. This may be due to protective

TABLE I

Toxicity of nicotinanilide against different stages of Lymnaea luteola snails

\begin{tabular}{|c|c|c|c|c|}
\hline Stage & Regression equation & $\begin{array}{l}\text { Chi Square } \\
(p>0.05)\end{array}$ & $\begin{array}{l}\mathrm{LC}_{50} \\
(\mathrm{ppm})\end{array}$ & $\begin{array}{l}\mathrm{LC}_{90} \\
(\mathrm{ppm})\end{array}$ \\
\hline $\begin{array}{l}\text { Eggs } \\
(0-24 \text { h old })\end{array}$ & $Y=6.53+2.12 X$ & 3.88 & $\begin{array}{c}0.19 \\
(0.16-0.22)\end{array}$ & $\begin{array}{c}0.76 \\
(0.57-1.02)\end{array}$ \\
\hline $\begin{array}{l}\text { Eggs } \\
\text { (72-96 h old) }\end{array}$ & $Y=6.56+1.84 X$ & 0.08 & $\begin{array}{c}0.14 \\
(0.12-0.17)\end{array}$ & $\begin{array}{c}0.70 \\
(0.47-1.04)\end{array}$ \\
\hline $\begin{array}{l}\text { Immature } \\
\text { (3-6 mm size) }\end{array}$ & $Y=6.76+2.73 X$ & 7.62 & $\begin{array}{c}0.23 \\
(0.20-0.25)\end{array}$ & $\begin{array}{c}0.67 \\
(0.54-0.82)\end{array}$ \\
\hline $\begin{array}{l}\text { Young mature } \\
(9-12 \mathrm{~mm} \text { size })\end{array}$ & $Y=5.31+2.83 X$ & 0.55 & $\begin{array}{c}0.77 \\
(0.69-0.86)\end{array}$ & $\begin{array}{c}2.32 \\
(1.78-3 . .03)\end{array}$ \\
\hline $\begin{array}{l}\text { Adults } \\
\text { (more than } 12 \mathrm{~mm} \text { ) }\end{array}$ & $Y=5.81+3.57 X$ & 4.75 & $\begin{array}{c}0.59 \\
(0.54-0.6)\end{array}$ & $\begin{array}{c}1.39 \\
(1.19-1.64)\end{array}$ \\
\hline
\end{tabular}

Values in the brackets are fiducial limits $95 \%$ 


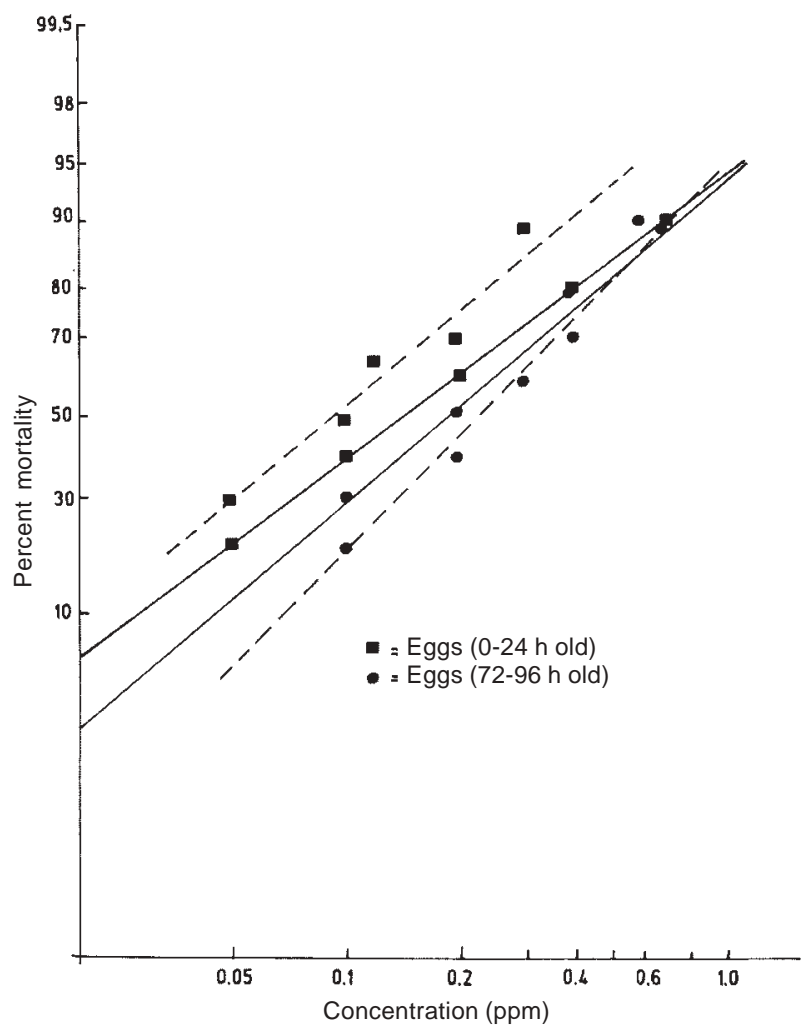

Fig. 1: concentration-mortality regression lines of two intracapsular stages of eggs of Lymnaea luteola exposed to nicotinanilide (and niclosamide(- - ).

covering of capsular jelly like material that covers and protects the freshly laid eggs from the external environment. A similar observation was also reported for nicotinanilide by Parashar et al. $(1995,1990)$ against $L$. auricularia $\left(\mathrm{LC}_{90}\right.$ value against 0 to 1 day and 4 to 5 days old eggs as $1.03 \mathrm{mg} / \mathrm{l}$ and $0.57 \mathrm{mg} / \mathrm{l}$ respectively) and the eggs of Indoplanorbis exustus (the $\mathrm{LC}_{90}$ value as 0.087 $\mathrm{mg} / \mathrm{l})$. The values of $\mathrm{LC}_{50}$ of 4 '-chloronicotinanilide against
1 to 4 days old eggs of Biomphalaria glabrata was reported as 10 ppm (Dunlop et al. 1980, Duncan \& Brown, 1983). The ovicidal action of niclosamide against the eggs of L. luteola was also found to increase with the age of the eggs. Parashar et al. (1995) reported a similar trend in the ovicidal action of niclosamide against the eggs of $L$. auricularia. Copper sulphate also induced similar effects against the eggs of Taphius glabratus and in the embryonic developmental stage of B. pfeifferi (Shiff et al. 1970). The extracts of few plant molluscicides like Euphorbia splendens, Phytolacca dodecandra, Tetrapleura tetraptera were also reported to exhibit lower toxicity towards earlier developmental stages than adults (DeSouza et al.

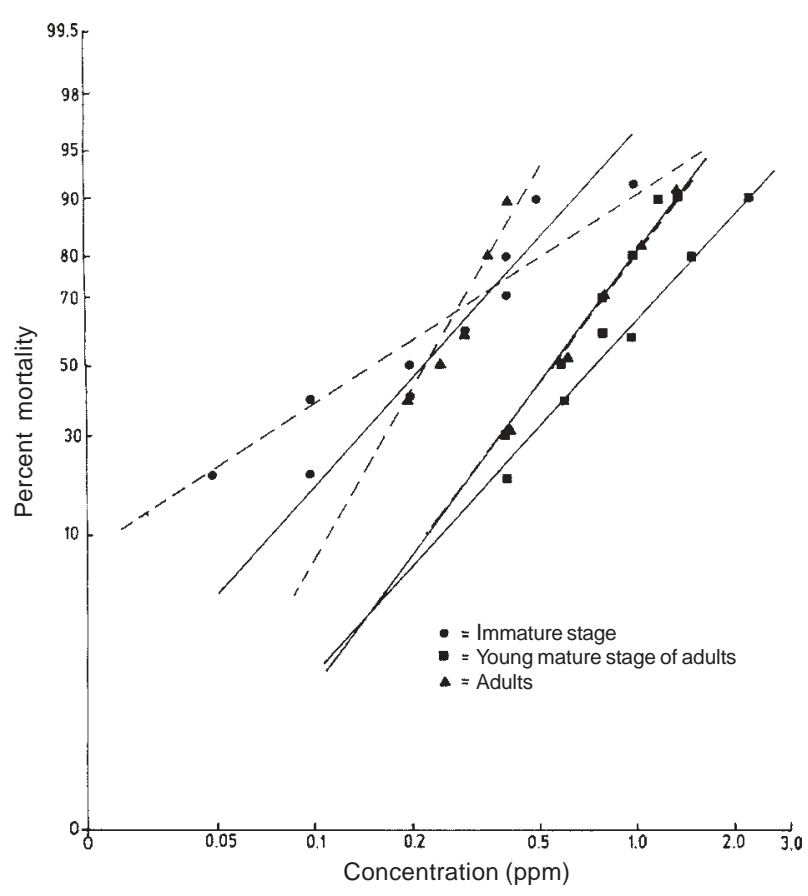

Fig. 2: concentration-mortality regression lines of different growing stages of Lymnaea luteola snails exposed to nicotinanilide (-) and niclosamide (- - -).

TABLE II

Toxicity of niclosamide against different stages of Lymnaea luteola snails

\begin{tabular}{|c|c|c|c|c|}
\hline Stage & Regression equation & $\begin{array}{c}\text { Chi Square } \\
(p>0.05)\end{array}$ & $\begin{array}{l}\mathrm{LC}_{50} \\
(\mathrm{ppm})\end{array}$ & $\begin{array}{c}\mathrm{LC}_{90} \\
(\mathrm{ppm})\end{array}$ \\
\hline $\begin{array}{l}\text { Eggs } \\
(0-24 \text { h old })\end{array}$ & $Y=6.75+2.69 X$ & 3.24 & $\begin{array}{c}0.22 \\
(0.20-0.25)\end{array}$ & $\begin{array}{c}0.71 \\
(0.53-0.94)\end{array}$ \\
\hline $\begin{array}{l}\text { Eggs } \\
\text { (72-96 h old) }\end{array}$ & $Y=7.17+2.12 X$ & 3.88 & $\begin{array}{c}0.09 \\
(0.08-0.11)\end{array}$ & $\begin{array}{c}0.38 \\
(0.28-0.51)\end{array}$ \\
\hline $\begin{array}{l}\text { Immature } \\
\text { (3-6 mm size) }\end{array}$ & $Y=6.25+1.61 X$ & 5.89 & $\begin{array}{c}0.16 \\
(0.14-0.20)\end{array}$ & $\begin{array}{c}1.04 \\
(0.67-1.63)\end{array}$ \\
\hline $\begin{array}{l}\text { Young mature } \\
\text { (9-12 mm size) }\end{array}$ & $Y=5.83+3.49 X$ & 0.33 & $\begin{array}{c}0.57 \\
(0.52-0.63)\end{array}$ & $\begin{array}{c}1.41 \\
(1.14-1.76)\end{array}$ \\
\hline $\begin{array}{l}\text { Adults } \\
\text { (more than } 12 \mathrm{~mm} \text { ) }\end{array}$ & $\mathrm{Y}=8.02+4.88 \mathrm{X}$ & 6.36 & $\begin{array}{c}0.24 \\
(0.22-0.25)\end{array}$ & $\begin{array}{c}0.45 \\
(0.40-0.51)\end{array}$ \\
\hline
\end{tabular}

Values in the brackets are fiducial limits $95 \%$ 


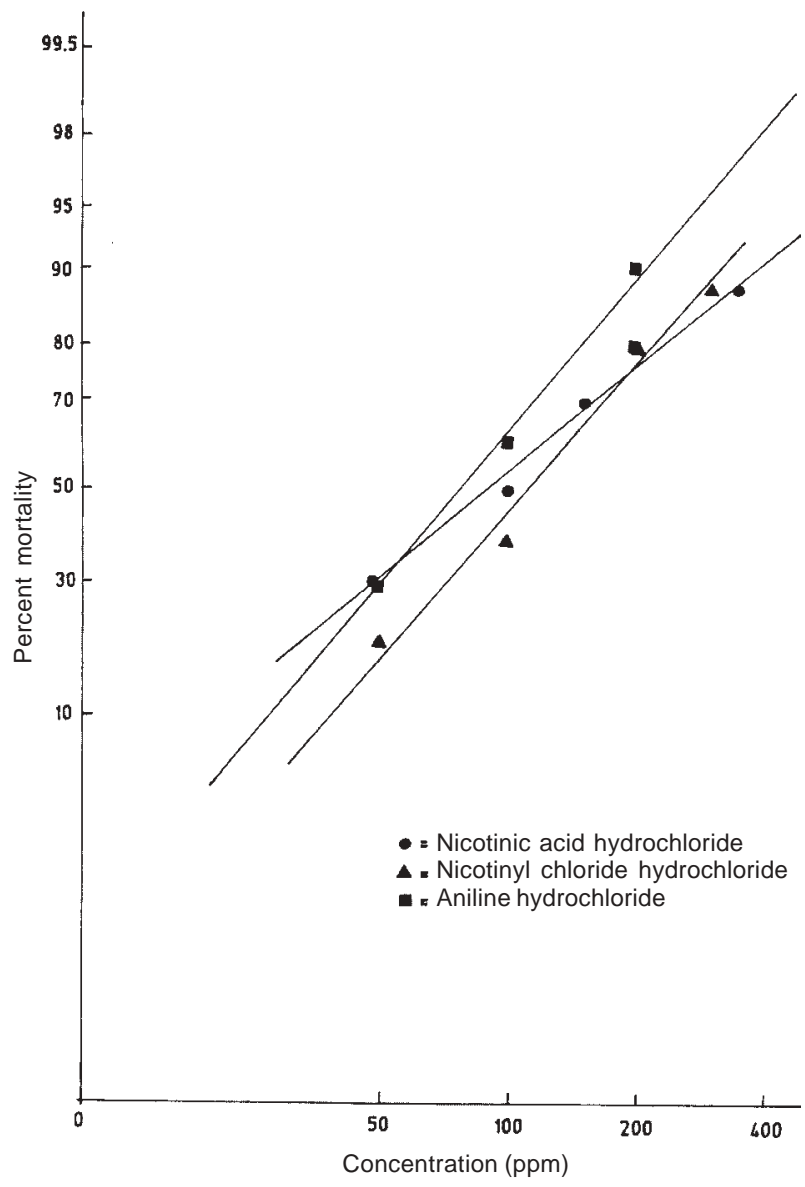

Fig. 3: concentration-mortality regression lines of intermediate compounds of nicotinanilide against young mature stage of adults of Lymnaea luteola snails.

1987, Schall et al. 1988, Adewunmi,1991). On the contrary, the jelly like egg protectant covering ova in L. natalensis was reported to be easily penetrated by niclosamide and produced 100\% mortality (Gillet \& Bruaux 1962). Zhang and Guo (1992) reported that the eggs of Oncomelania snails exposed to bromoacetamide showed the deformation in the earlier stages but not in the later stages. Sukumaran et al. $(1994,1995,2002)$ also reported the $n-$ butanol extracts of some plant molluscicides like Sapindus trifoliatus, Agave americana, Balanites aegyptica, Jat- ropha gossypifolia, and Vaccaria pyramidata as toxic against freshly laid eggs of L. luteola.

Studies on the toxicity of both nicotinanilide and niclosamide against different growing stage of $L$. luteola snails indicated both the compounds as more toxic to both immature and adult stages of the snails than the young mature stage. Parashar et al. (1990) also reported the toxicity of nicotinanilide against $I$. exustus snails and indicated the young adult stage as least susceptible. The reason may be that the young mature adult stage of the $L$. luteola snails is highly active and reproductive and hence more tolerant to the different environmental stress (changes in $\mathrm{pH}$, hardness of water, and different pollutants including pesticides and molluscicides) present in the aquatic medium. In this study, the toxicity of niclosamide against young mature stage of $L$. luteola was found to be 1.64 times higher than nicotinanilide. Niclosamide is also reported as more toxic than nicotinanilide against young mature stage of $L$. auricularia (Parashar et al. 1995).

Toxicity of intermediates of nicotinanilide against the young mature stages of $L$. luteola shows them as very poor molluscicides as illustrated by their higher $\mathrm{LC}_{90}$ values. The acidic moiety of niclosamide namely 2'5-dichloro 4 '-aminosalicylanilide is reported to loose all its molluscicidal properties and found ineffective in killing snails (Struff 1964, Struff \& Gonnert 1967).

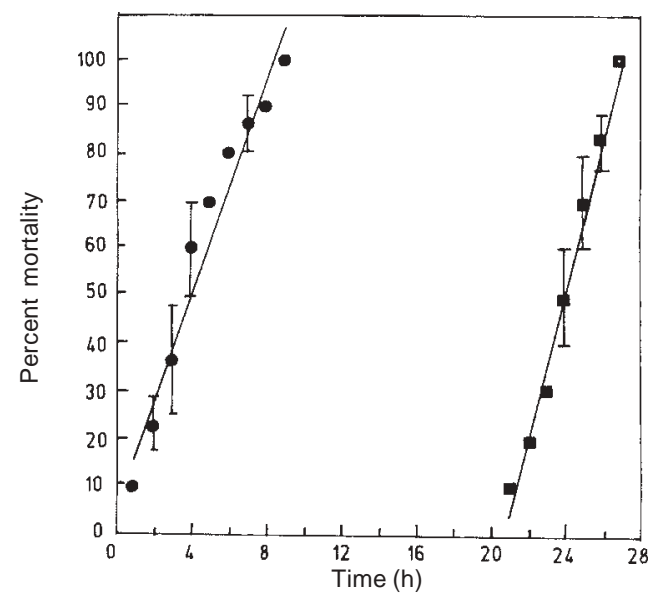

Fig. 4: mortality pattern of the young mature stage of adults of Lymnaea luteola snails exposed to $\mathrm{LC}_{90}$ concentration of nicotinanilide $(\mathbf{\bullet})$ and niclosamide $(\bullet)$.

TABLE III

Toxicity of intermediates of nicotinanilide against young mature stages of Lymnaea luteola snails

\begin{tabular}{|c|c|c|c|c|}
\hline Compound & Regression equation & $\begin{array}{l}\text { Chi Square } \\
(p>0.05)\end{array}$ & $\begin{array}{l}\mathrm{LC}_{50} \\
(\mathrm{ppm})\end{array}$ & $\begin{array}{l}\mathrm{LC}_{90} \\
(\mathrm{ppm})\end{array}$ \\
\hline $\begin{array}{l}\text { Nicotinic acid } \\
\text { hydrochloride }\end{array}$ & $Y=0.58+2.25 X$ & 1.01 & $\begin{array}{c}89.77 \\
(76.39-105.50)\end{array}$ & $\begin{array}{c}371.32 \\
(247.45-557.20)\end{array}$ \\
\hline Aniline hydrochloride & $\mathrm{Y}=0.71+2.80 \mathrm{X}$ & 2.47 & $\begin{array}{c}108.46 \\
(95.48-123.21)\end{array}$ & $\begin{array}{c}310.87 \\
(232.52-415.62)\end{array}$ \\
\hline $\begin{array}{l}\text { Nicotinyl chloride } \\
\text { hydrochloride }\end{array}$ & $Y=0.58+2.95 X$ & 0.59 & $\begin{array}{c}77.55 \\
(68.19-88.21)\end{array}$ & $\begin{array}{c}210.39 \\
(167.02-265.03)\end{array}$ \\
\hline
\end{tabular}

Values in the brackets are fiducial limits $95 \%$ 
The studies on the mortality pattern of L. luteola snails show that niclosamide requires less time for complete mortality of the snails than nicotinanilide. The rapid action of niclosamide in killing snails is due to its toxic effect on the respiratory function of the snails by acting as uncoupler of oxidative phosphorylation at the mitochondrial level (White House 1964, Andrews et al. 1983). Highest mortality of the L. luteola snails in this study was observed during the period between 6 and $8 \mathrm{~h}$ after exposure. In the case of $L$. cailliaudi the complete inhibition of oxygen uptake was observed after $6 \mathrm{~h}$ when the snails were exposed to $2 \mathrm{mg} / \mathrm{l}$ of niclosamide (Elgindy \& Mohamad 1976). In the case of nicotinanilide, mortality of the snails started only after $21 \mathrm{~h}$ of exposure, the slow molluscicidal action may require its accumulation into the body of the snail. Daffalla (1978) exposed B. glabrata snails to nicotinanilide and studied the thin layer chromatography of the chloroform extract of pseudobranch and reported only the presence of parent compound i.e., nicotinanilide but no metabolite.

From the point of view of safety to non-target organisms, fishes, and mammals, nicotinanilide may be regarded as a better option even though the $\mathrm{LC}_{90}$ value is 1.6 times higher than niclosamide. Hence, nicotinanilide can be recommended for selective killing of snails in schistosomiasis control programmes.

\section{ACKNOWLEDGEMENTS}

To K Sekhar, Director, Defence R\&D Establishment, Gwalior for his constant encouragement and support in completing this work. To M/S Bayer AG, Germany for giving bayluscide $70 \% \mathrm{WP}$ as a free sample for our research work.

\section{REFERENCES}

Adewunmi CO 1991. Subchronic exposure of Biomphalaria glabrata eggs to aridanin and niclosamide. J Ethnopharmacol 31: 209-216.

Agrawal MC, Gupta S, George J 2000. Cercarial dermatitis in India. Bull WHO 78: 278

Andrews P, Thyssen J, Lorke D 1983. The biology and toxicology of molluscicides, bayluscide. Pharmacol Therp 19: 245-295.

Cheng ZP, Tao HQ, Hua DS, Shen BR, Chan HL 1991. Evaluation of molluscicidal effect of nicotinanilide against $\mathrm{On}$ comelania snails. J Parasitol Parasitic Dis 9: 216-218.

Daffalla AAR 1978. The Relative Susceptibilities of Bulinus truncatus (Audouin) and Sarotherodon mossambicus (Peters) to Certain Molluscicides, PhD Thesis, University of London.

DeSouza CP 1995. Molluscicide control of snail vectors of schistosomiasis. Mem Inst Oswaldo Cruz 90: 165-168

DeSouza CP, Paulini E 1969. Laboratory and field-tests with three promising molluscicides non-toxic to fish. WHO unpublished document PD/Mol/69.7.

DeSouza CP, Mendes NM, Araujo N, Katz N 1987. Molluscicidal activity of a butanol extract of Phytolacca dodecandra (endod) on Biomphalaria glabrata. Mem Inst Oswaldo Cruz 82: 345-349.

Duncan J, Brown N 1983. Chronic exposure of the eggs and adults of Biomphalaria glabrata (Say) to the molluscicide nicotinanilide. Tropenmedizin and Parasitologie 34: 184186.

Dunlop RW, Duncan J, Brown N 1980. Quantitative structureactivity relationships for nicotinanilide molluscicide. Pesti- cide Science 11: 53-60.

El-Gindy HI, Mohamed AM 1976. Oxygen consumption of different sizes groups of Lymnaea cailliaudi especially after application of Bayer 73 or Mollutox. J Egypt Soc Parasitol 6: 95-104.

Engels D, Chitsulo L, Montresor A, Savioli L 2002. The global epidemiological situations of schistosomiasis and new approach to control and research. Acta Trop 82: 139-146.

Finney SJ 1971. Probit Analysis, Cambridge University Press, London.

Gillet J, Bruaux P 1962. A laboratory and field testing of (Bayer 73). Pflanzenschutz-Nachrichten Bayer 15: 70-74 (English edition).

Horak P, Kolarova L 2001. Bird schistosomes: Do they die in mammalian skin? Trends in Parasitol 17: 66-69.

Jairajpuri MS 1991. Snails, Flukes, and Man, Zoological Survey, India $60 \mathrm{pp}$.

Lardans V, Dissous C 1998. Snail control strategies for reduction in schistosomiasis transmission (Review). Parasitol Today 14: 413-417.

Madsen H, Christiansen NO 1992. Intermediate host of schistosomes: ecology and control. Bull Soc Vector Ecol 17: 2-9.

Malek EA, Cheng TC 1974. Medical and Economic Malacology, Academic Press, New York and London, 398 pp.

Marking LL, Horgan JW 1967. Toxicity of Bayer 73 to Fish. US Fish Wild Serv Invest Fish Center 19: 3-13.

Parashar BD, Kaushik MP, Gupta AK, Swamy RV, Rao KM 1995. Toxicity of some molluscicides to freshwater snail Lymnaea auricularia the vector of animal fasciolasis and to non-target organisms. Proc Acad Environ Biol 4: 183-187.

Parashar BD, Kaushik MP, ShriPrakash, Rao KM 1990. Toxicity of nicotinanilide and its analogues to the freshwater snail Indoplanorbis exustus, mediator of animal schistosomiasis and to non-target organism. J Med Appl Malacol 2: 135-140.

Schall VT, Mauricio CS, Souza CP, Baptista DF 1998. The molluscicidal activity of Crown Christ (Euphorbia splendens Var. Hislopii) latex on snails acting as intermediate hosts of Schistosoma mansoni and S. haematobium. Am J Trop Med Hyg 58: 7-10.

Schreier TM, Dawson VK, Choi Y, Spanjer NJ, Boogaard MA 2000. Determination of niclosamide residues in rainbow trout (Oncorhynchus mykiss) and channel catfish (Ictalurus punctatus) fillet tissue by HPLC. J Agric Food Chem 48: 2212-2215.

Shiff CJ, Barnish G, Yiannakis C, VanEde RJ 1970. Preliminary trials with Bayer 6076, a new liquid formulation of niclosamide. Pflanzenschutz Nachrichten Bayer 23: 99-104.

Singh O, Agarwal RA 1981. Toxicity of certain pesticides to two economic species of snail in northern India. J Econ Entomol 74: 568-571.

Struff R 1964. Zum Wirkungsmechanismus des Bandwurmmittels Yomesan. IIIrd Int. Cong. Chemotherapy, July 1963, Thieme Verlag. Stuttgart, p. 1544-1547.

Struff R, Gonnert R 1967.Uberdie Beeinflussung des Bandwurmstoffwechsels durch Arzneimittel. Z Tropenmed Parasit 18: 193-202.

Sturrock RF 1995. Current concepts of snail control. Mem Inst Oswaldo Cruz 90: 241-248.

Sturrock RF 2001. Schistosomiasis epidemiology and control: How did we get here and where should we go? Mem Inst Oswaldo Cruz 96 (Suppl.): 17-27.

Sukumaran D, Parashar BD, Rao KM 1994. Molluscicidal properties of Agave americana and Balanites aegyptica. Int J Pharmacognosy 32: 232-238.

Sukumaran D, Parashar BD, Rao KM 1995. Toxicity of ex- 
tracts Jatropha gossypifolia and Saponaria saponaria as molluscicide against freshwater snails Lymnaea luteola and Indoplanorbis exustus, the vectors of animal schistosomiasis. Fitoterapia LXVI : 393-398.

Sukumaran D, Parashar BD, Rao KM 2002. Evaluation of some plant molluscicides against a freshwater snail Lymnaea luteola, the vector of animal schistosomiasis. Pharmaceutical Biol 40: 450-455.

Tang C, He CH, Quin CR 1986. Observation on the effect of nicotinanilide on Schistosoma japonicum cercariae. Natl Med J China 66: 555.

Xiao S, Tanner M, N'Goran EK, Utzinger J, Chollet J, Bergquist R, Minggang C, Fiang Z 2002. Recent investigation of artemether, a novel agent for the prevention of Schistosoma japanicum, S. mansoni, and S. hematobia. Acta Trop 82: 175-181.
Wang GF, Sung, GM 1990. Preliminary research and study of the transaminase of Oncomelania snail. J Parasitol Parasitic Dis China 8: 110-112.

White House MM 1964. Report of salicylanilide as decouplers of oxidative phosphorylation in rat mitochondria. Biochem Pharmacol 13: 319.

WHO 1965. Molluscicide screening and evaluation. Bull WHO 33: 567-581.

WHO 1992. Role of Mollusciciding in Schistosomiasis Control, Fergus S McCullough, WHO/Schisto/92, 107, 34 pp.

WHO 1993. The Control of Schistosomiasis, Second Report of the WHO Expert Committee, WHO Tech Rep Ser 830, WHO, Geneva.

ZhangY, Guo YH 1992. Study on the effect of bromoacetamide upon the development of snail eggs. $J$ Parasitol Parasitic Dis 10: 258-262. 